\title{
Introduction to the special issue: Public Procurement-new theoretical and empirical developments
}

\author{
Stéphane Saussier ${ }^{1}$ Paola Valbonesi ${ }^{2,3}$
}

Received: 10 January 2018 / Accepted: 13 January 2018 / Published online: 29 January 2018 (C) Associazione Amici di Economia e Politica Industriale 2018

The public sector is facing an unprecedented request to become more efficient and effective in light of - on the one hand-tight budgets and financial cutbacks at each governance level, and — on the other hand-the rising demand for services, goods and furnitures to be procured by public administrations. As a consequence, the design and management of public procurement-i.e., in the form of procurement contracts, public service delegation and public-private partnerships, accounting for up to $15 \%$ of GDP in OECD countries (OECD, 2013) - has become an even more important priority.

As stressed by Laffont and Tirole (1993), ${ }^{1}$ to investigate a theory of procurement one should take into consideration three main types of regulatory constraints: informational, transactional, and administrative and political. Such constraints differently affect the main phases through which the public procurement process is usually implemented, that is: (i) planning the good/service/furniture to be procured (planning stage); (ii) placing/awarding a contract to acquire such good/service/furniture to a contracting partner (selection stage); and (iii) administering/monitoring the contract performance (execution stage). Furthermore, each of these phases could be differently organized according to the good/service/furniture to be procured. As

\footnotetext{
1 See the Introduction of "A theory of incentives in procurement and regulation", p. 1.

Paola Valbonesi

paola.valbonesi@unipd.it

Stéphane Saussier

saussier@univ-paris1.fr

1 Institut d'Administration des Entreprises (IAE) - Université Paris 1 (Panthéon-Sorbonne), Paris, France

2 Dipartimento di Studi Economici e Aziendali "Marco Fanno", Universita' di Padova, Padua, Italy

3 Higher School of Economics - National Research University, Moscow, Russia
} 
a consequence, in real practice, the procurement design and management result in a very complex and dynamic process where strategic decisions by the involved parts (i.e., in particular, public buyers, supplier firms and third parties) should interact directly with contractual issues, competition and risk-sharing problems, supplychain and demand-supply relationships (Dimitri et al. 2006).

In a recent paper, Saussier and Tirole (2015)-discussing the new flexibility given by the European Directives on Public Procurement ${ }^{2}$ in the selection and execution stages-highlighted the relevance of the public authorities' ability and experience in running the procurement process. This is a key point as institutions are endogenous: the effects of the many constraints they face in the procurement process implementation are still unknown — or in a state of conjecture-and need to be carefully investigated in a number of aspects. Indeed, notwithstanding the extensive and up-dated literature on public procurement, economic research is largely lagging behind in explaining why many public procurement rules and policies are efficient and effective in some settings (i.e., municipalities/regions/countries), but not in others.

In this perspective, the Special Issue on Public Procurement: new theoretical and empirical developments points at presenting research that addresses issues largely related to the public buyers' choices in the procurement process. Our hope is that this Special Issue will not only provide an overview of selected topics in procurement and shed lights on some new issues, but also-more importantly-motivate future high-quality research papers in this area.

Our work as Invited Editors has been supported by some important cooperations. Our thanks go to five excellent ad hoc referees, who provided additional expertise: Laure Athias (University of Lausanne, IDHEAP); Jean Beuve (Université Paris I Panthéon-Sorbonne); Eshien Chong (Université Paris I Panthéon-Sorbonne); Michele Moretto (DSEA, University of Padova); Carine Staropoli (Paris School of Economics-Université and Paris I Panthéon-Sorbonne).

We also want to thank Laura Rondi and Carlo Cambini-Editors of Economia e Politica Industriale-Journal of Industrial and Business Economics-for commissioning the project, and for their continuous encouragement.

\section{Contents}

The Special Issue begins with the paper by Moszoro and Spiller on the "Implication of Third Parties for Contract Design": the authors, specifically referring to public procurement contracts, highlight the major role played by third parties, i.e., players tacitly engaged, but not formally involved in a contractual relationship (e.g., watchdogs, minorities, advocacy groups, consumers, past and future transactors, and opponents and competitors to the contractees). These third parties may challenge,

\footnotetext{
2 They refer to the Directives 2014/24/EU on the awarding of public procurement contracts (i.e. the 'classic' sectors) and 2014/25/EU on the awarding of contracts in the water, energy, transport and postal services sectors (i.e. the 'special' sectors), Official Journal of the European Union, 28 March 2014; furthermore, to the Directive 2014/23/EU of the European Parliament adopted by the European Parliament on 15 January 2014.
} 
either informally through the media or formally in a court, the legitimacy of the transaction. This could provide—on the one side-a desirable instrument of oversight and - on the other side-a pernicious opportunistic tool. Focusing on the latter, the paper extends the theoretical framework in Spiller $(2008,2013)$ and Moszoro and Spiller $(2012,2014)$ to investigate the implications of third parties for procurement contract design, corporate governance and sequential exchanges.

Next, a survey paper by Camboni Marchi Adani on "Procuring price and quality using scoring auctions: where do we stand?" presents an overview of the main theoretical and empirical results gained in the economic (and operational) literature on procurement scoring rule auctions (also called multiattribute/multidimensional auctions). Furthermore, the paper describes a structural estimation on datasets collecting scoring rule auctions, using a step-by-step procedure that can be reproduced by researchers and practitioners. It moreover discusses the key challenges a practitioner must consider when implementing such auctions, as well as those a researcher faces when assembling data to investigate them. Finally, the paper highlights the gaps in the literature that warrant the attention of researchers.

Recent applications of scoring rule auctions are to be recorded in green public procurement (GPP), i.e. the purchasing process by which public authorities procure goods/services/furniture with a reduced environmental impact. The paper by Lundberg and Marklund on "Green Public Procurement and Multiple Environmental Objectives" investigates whether GPP can be used to effectively achieve multiple environmental objectives. The authors investigate GPP where the allocation mechanism is a competitive tendering, and environmental concerns may be expressed as environmental requirements on the producer (potential supplier), on the production process (vertical dimension), or on the supply of the good/service/furniture. Consequently, the environmental performance of the potential supplier and the product are parts of the quality offer, i.e., the auction rule takes the form of multidimensional bidding with a price bid and one-or more-quality offer(s). The paper develops a formal analysis referring to a consistent system of environmental policy instruments and discusses implications for Cleaning Products and Services and Food and Catering Services, i.e. the two sectors identified by the European Commission as priority sectors for implementing GPP. The main conclusion that follows from the analysis is that GPP is not an effective environmental policy instrument.

Effective competition in the awarding procedures is often seen as a way to alleviate the negative effects of firms' misbehaviour (i.e. collusion) and of public buyers' corruption. The paper by Finocchiaro Castro, Guccio, Pignataro and Rizzo on "Is competition able to counteract the inefficiency of corruption? The case of Italian public works" estimates a relative inefficiency index based on cost and time overruns for a sample of roadwork construction and repair contracts in Italy, using nonparametric DEA technique. It then correlates the index with objective measures of corruption at the provincial level and the intensity of competition for the contract, as measured by the winning rebate and bidders' turnout. The paper finds that more competition magnifies the negative effects of corruption on the efficiency of public procurement for roadwork construction and repairs, and interprets this result as suggesting that more intense competition encourages firms to resort to corruption in order to renegotiate ex-post and recoup their gains. 
The entry of foreigneir firms in the supply of procurement goods, services and furniture-i.e., free cross border procurements-is considered as an indirect way to increase competition in the awarding phase and expose governments to international best practices and experiences. The paper by Carboni, Iossa and Mattera on "Barriers Towards Foreign Firms in International Public Procurement Markets: A Review" provides an extended review of procurement barriers to foreign firms and products, as well as of the methodologies in the economic literature addressing the discrimination towards foreign firms in public procurement. The paper focuses on identification issues and data availability, and the authors suggest different ways to improve on data collection for the needed analysis on this topic, in particular referring to the qualitative assessment of discrimination in procurement markets.

Enjoy the reading!

\section{References}

Dimitri, N., Piga, G., \& Spagnolo, G. (2006). Handbook of procurement. Cambridge: Cambridge University Press.

Laffont, J.-J., \& Tirole, J. (1993). A theory of incentives in procurement and regulation. Cambridge, MA: MIT Press.

Moszoro, M., \& Spiller, P. T. (2012). Third-party opportunism and the nature of public contracts. NBER Working Paper 18636, National Bureau of Economic Research.

Moszoro, M. W., \& Spiller, P. T. (2014). Third-party opportunism and the theory of public contracts: Operationalization and applications. In E. Brousseau and J.-M. Glachant (Eds.), The Manufacturing of Markets: Legal, Political and Economic Dynamics, Chapter 11, pp. 229-252. Florence: Cambridge University Press.

OECD. (2013). Government at a Glance 2013. OECD Publishing (Government at a Glance). Retrieved November 20, 2000, from http://www.oecd-ilibrary.org/governance/government-at-a-glance-2013_ gov_glance-2013-en.

Saussier, S. and Tirole, J. (2015). Strengthening the efficiency of public procurement. 22. French Council of Economic Analysis. Retrieved from www.cae-eco.fr/IMG/pdf/cae-note022-env2.pdf.

Spiller, P. T. (2008). An institutional theory of public contracts: Regulatory implications. NBER Working Paper 14152, National Bureau of Economic Research.

Spiller, P. T. (2013). Transaction cost regulation. Journal of Economic Behavior \& Organization, 89, 232-242. 